\title{
Chemical and Physicochemical Characteristics of Dissolved Organic Carbon Circulating in Harmonic Lake Biwa, Japan*
}

\author{
Toshitaka HoRI, Yuko SugIYAMA and Masahito SUgIYama
}

\begin{abstract}
In parallel with the monitoring of the distribution profiles of dissolved organic carbon (DOC) in Lake Biwa, Japan, the adsorption characteristics of DOC onto an adsorbent of hydrous iron oxide (HIO) was investigated by varying the $\mathrm{pH}$ of the lake water samples from 11.5 to 3.6. The first sign of the adsorption of DOC appeared around $\mathrm{pH} 8.5$; the adsorption percentage increased sharply as the $\mathrm{pH}$ decreased and reached a constant value around $60 \%$ at $\mathrm{pH} 4-6$, followed by a rapid decrease to $0 \%$ below $\mathrm{pH} 4.0$. By utilizing the flat region ( $\mathrm{pH} \mathrm{4-6)}$ of the adsorption percent, the total DOC (tot-DOC) was separated into two fractions; the adsorption active (act-DOC) fraction and the inert (int-DOC) fraction. The latter showed a steady concentration around $0.4 \mathrm{mg} \mathrm{C} \mathrm{m}^{-1}$ in the lake throughout a one-year period, whereas the former showed variations between 0.7 and $1.2 \mathrm{mg}$ $\mathrm{C}^{-1}$ depending on the season. Act-DOC was found to be reactive with permanganate ion, and the amounts of permanganate consumed for the reaction can be described as follows: the chemical oxygen demand $(\mathrm{COD})\left(\mathrm{mg} \mathrm{O}_{2} \mathrm{l}^{-1}\right)=0.97 \times$ act-DOC $\left(\mathrm{mg} \mathrm{C} \mathrm{l}^{-1}\right)-0.50$, where COD is the concentration of an equivalent amount of oxygen demanded for the oxidation. The chemical characteristics and the origin of act-DOC are discussed in light of the values of the slope and intercept of the linear relation. The int-DOC fraction had no such clear relation to COD and appeared to remain as a refractory fraction of organic carbons occurring in the lake.
\end{abstract}

Key words : dissolved organic carbon, distribution, chemical oxygen demand, Lake Biwa

\section{INTRODUCTION}

To determine the chemical, biochemical, and physicochemical nature of dissolved organic carbon (DOC), OGURA (1972) incubated in tightly capped glass vessels a series of seawater samples taken from Tokyo Bay and kinetically measured the decreases in DOC over time. He observed two

* Environmental Chemistry of Rivers and Lakes, Part IV. For Part III, see reference Hori et al. (1997). 
different rates in the decay of labile DOC, concluding that about $50 \sim 60 \%$ of the DOC is biodegradable and the rest is refractory. The presence of refractory DOC, which had been well studied in soil chemistry, was thus substantiated also in natural water chemistry. OGURA $(1974,1975)$ subsequently separated total DOC into four fractions by ultrafiltration through Diaflo ${ }^{\circledR}$ membranes and found that the biodegradable fraction is the one with a lower molecular weight of less than 500 dalton.

More recently, AMON and BERNER (1994) applied the tangential flow separation technique for DOC collected from the surface of a pelagic part of the North Pacific Ocean and reported that the biodegradable fraction had a molecular weight higher than 1000 dalton. As for DOC in the open seas, it is now thought that the higher molecular DOC is degradable and the lower molecular DOC is refractory: However, there is still some controversy about the nature of DOC in river and lake water as well as in the seawater around coastal regions, because the production and degradation processes of organic carbon are quite complicated due to the high bioactivity. Nevertheless, the nature of DOC in these types of waters has a direct and strong influence on the water needed for our lives and social activities.

We report here the distribution and variation in, together with the chemical and physicochemical characteristics of, DOC circulating in Lake Biwa, Japan, on the basis of both field observation and laboratory experiments on DOC. The latter included the measurements of the adsorptivity of DOC to hydrous iron oxide (HIO) suspension and its lability against permanganate oxidant.

\section{REAGENTS AND APPARATUS}

Polycarbonate sample bottles (1 liter) and polycarbonate centrifugation tubes $(85 \mathrm{ml}$ ) with screw caps were cleaned by soaking them in baths of $10 \%$ $\mathrm{Scat}^{\circledR}$ and $4 \mathrm{M} \mathrm{HCl}$, followed by rinsing thoroughly with water purified by a Milli-Q SP TOC ${ }^{\circledR}$ system (MQ-water). When glass vessels were used in place of polycarbonate vessels, they were further cleaned by steam. Blank tests ensured that the contamination of organic carbon eluted from these vessels after cleaning was below the $0.01 \mathrm{mg} \mathrm{Cl}^{-1}$ level, which was negligible compared to the DOC concentrations in Lake Biwa (1.0-1.5 $\left.\mathrm{mg} \mathrm{C}^{-1}\right)$.

Nuclepore ${ }^{\circledR}$ filters $(0.4 \mu \mathrm{m}$ pore, $47 \mathrm{~mm}$ diameter) used for the preparation of DOC samples were cleaned by heating them in a bath of a 1M HCl $-1 \mathrm{M} \mathrm{HNO}_{3}$ mixture, followed by rinsing with 1 liter of MQ-water. The contaminative elution of DOC from 10 sheets of filters thus treated was less than the background concentration $\left(\sim 0.01 \mathrm{mg} \mathrm{Cl}^{-1}\right)$ of organic carbon in the MQ-water.

An adsorbent of HIO was prepared as follows. Commercially available reagent-grade $\mathrm{FeCl}_{3} \cdot 6 \mathrm{H}_{2} \mathrm{O}(2.90 \mathrm{~g})$ was dissolved in $5 \mathrm{M} \mathrm{HCl}(20 \mathrm{ml})$ and mixed with $2 \mathrm{M} \mathrm{NH}_{3}(60 \mathrm{ml})$. The precipitates thus formed were washed 5 times with MQ-water $(20 \mathrm{ml})$ and dispersed in MQ-water $(30 \mathrm{ml})$. The HIO suspension was freshly prepared before use to keep it in an amorphous state. 
For the adsorption experiment on DOC, 2-ml aliquots of the suspension, each of which included $40 \mathrm{mg} \mathrm{Fe}$, were used.

Commercially available bovine serum albumin (BSA, Sigma Chemical Co., St. Louis, MO, USA) and soluble starch (Wako Chemicals, Osaka, Japan) were used as reference standard materials for the measurements of chemical oxygen demand (COD). Humic and fulvic acids were also used as standard materials. These acids were extracted from sediment taken from Lake Biwa and purified according to the standard procedure (AIKEN et al., 1985) with minor modifications (TAKAMATSU, 1985).

The concentrations of DOC were measured by the high-temperature catalytic oxidation method by using a total organic carbon analyzer (TOC 5000, Shimadzu, Kyoto, Japan).

The COD was determined by the standard method (Japan Waterworks Association, 1985), in which a $50-\mathrm{ml}$ aliquot of the sample was mixed with $10 \mathrm{ml}$ of $0.01 \mathrm{~N}$ permanganate solution at $80^{\circ} \mathrm{C}$ for $30 \mathrm{~min}$ under acidic condition using $5 \mathrm{ml}$ of $\mathrm{H}_{2} \mathrm{SO}_{4}(1+3)$.

In parallel with the measurements of DOC and COD, the concentrations of $\mathrm{Si}, \mathrm{P}$, ammonia- $\mathrm{N}$, nitrate- $\mathrm{N}$ and $\mathrm{Al}$ were also measured (HoRI et al., 1996) along with the monitoring of $\mathrm{pH}$, dissolved oxygen, chlorophyll- $a$, and water temperature (Center for Ecological Research, Kyoto Univ.).

\section{FIELD OBSERVATIONS}

\section{Observation settings}

Lake Biwa $\left(35^{\circ} 5^{\prime} \mathrm{N}, 136^{\circ} 5^{\prime} \mathrm{E}\right.$, Shiga Prefecture, Japan), a typical harmonic lake in Japan, contains $27.3 \mathrm{~km}^{3}$ of fresh water and supports the daily use of water by 14,000,000 residents in the Kinki district. The phosphorus concentration of the lake started to increase in 1965 (FUJINAGA and HoRI, 1982), and the lake's eutrophication has since been anticipated. Although a local law enforced since 1985 regulating the use of phosphorus in the watershed area of the lake fortunately retarded the increase in the phosphorus concentration, the quality of the lake water is not yet restored and the COD is still increasing (MATSUI and ARIYOSHI, 1995). Even the depletion of dissolved oxygen in the bottom water is occasionally observed (YoshioKA, 1991) due to the accumulation of organic carbons in the hypolimnion.

The lake consists of two basins ; the northern basin is the main basin and has a surface area of $616 \mathrm{~km}^{2}$ and a capacity of $27.1 \mathrm{~km}^{3}$, with average and maximum depths of $44 \mathrm{~m}$ and $104 \mathrm{~m}$, respectively; the southern sub-basin has a surface area of $58 \mathrm{~km}^{2}$ and a capacity of $0.2 \mathrm{~km}^{3}$, with average and maximum depths of $3.5 \mathrm{~m}$ and $8 \mathrm{~m}$, respectively.

The sampling site Ie-1 (73 $\mathrm{m}$ depth) is located in the main basin, which nowadays exhibits a mesotrophic nature. In the northern basin, thermal stratification typically occurs from May to December, and convection of the lake water occurs regularly from January to April. The sampling site Akanoi (2 $\mathrm{m}$ depth) is located at the mouth of Akanoi Bay situated along the northeast coast of the sub-basin. The Moriyama River runs into this bay and 
brings nutritious elements wasted along the river; the bay and the Akanoi site exhibit typically eutrophic phenomena, e.g., blooming of Urogrena americana and a few species of Microcystis (Shiga Pref., 1995) in summer.

\section{Sampling and sample treatments}

At site Ie-1, 1-liter samples were taken at depths of $0,1,5,10,15,20$, $30,40,50,60,70$ and $73 \mathrm{~m}$ (bottom), at intervals of 1 month during the period from June 1993 to September 1995. At Akanoi, samples were taken at the surface during the same period.

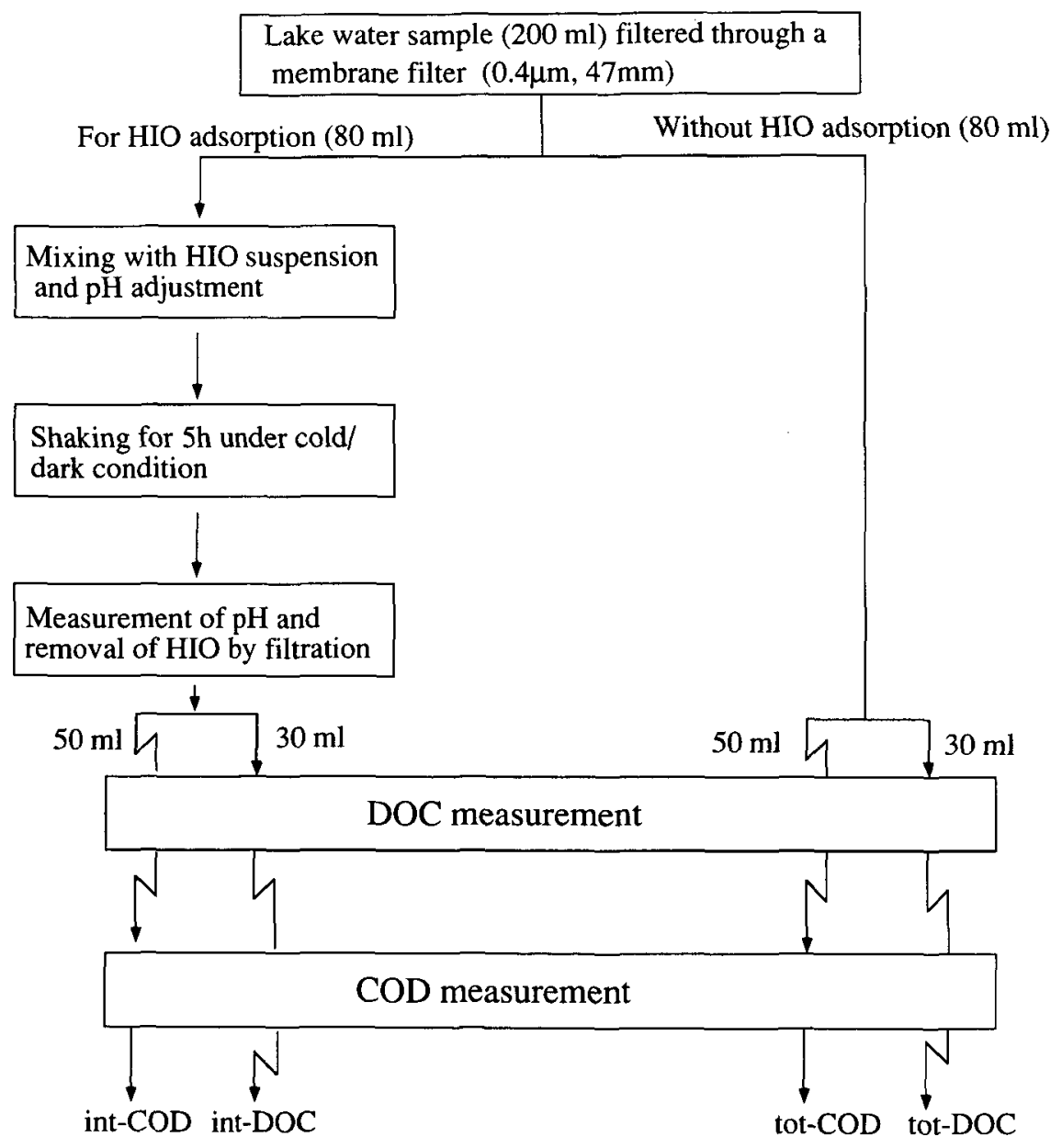

Fig. 1. Procedures for the measurements of total dissolved organic carbon (tot-DOC), inert (int)-DOC, total chemical oxygen demand (tot-COD), and inert (int) - COD. Active (act) -DOC and act-COD were calculated as follows : act-DOC $=$ tot-DOC - int-DOC, act-COD $=$ tot-COD - int-COD. $\mathrm{HIO}$ : hydrous iron oxide. 
The samples collected in polycarbonate bottles were brought back to the laboratory under ice-cooled and dark conditions. As shown in Fig. 1, approximately $100-\mathrm{ml}$ aliquots of the samples were filtered by the previously cleaned Nuclepore ${ }^{\circledR}$ filters and subjected to the DOC and COD measurements and the adsorption experiments. When long-term storage was unavoidable before the DOC measurements, the filtered samples were frozen at $-30^{\circ} \mathrm{C}$.

\section{Vertical distribution of DOC observed at site Ie-1}

Figure 2 shows the serial changes in the vertical distribution of DOC observed at site Ie-1 during the period from November 1993 to March 1995. When the stratification occurred (May to December), the DOC in the epilimnion (above the thermocline indicated in the Figure) varied in a concentration range of $1.0-1.6 \mathrm{mg} \mathrm{C} \mathrm{^{-1 }}$, and the DOC in the hypolimnion varied between 1.0 and $1.8 \mathrm{mg} \mathrm{C} \mathrm{^{-1 }}$. When the lake water circulated (February to May), the DOC concentration became uniform (around $1.0 \mathrm{mg}$ $\mathrm{C}^{-1}$ ) in the entire lake. In the warm season (May to September), the DOC in the surface layer started to increase from 1.0 up to $1.6 \mathrm{mg} \mathrm{Cl}^{-1}$, whereas in the bottom layer the DOC remained relatively low $\left(1.2 \mathrm{mg} \mathrm{C}^{-1}\right)$ except

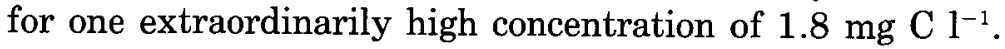

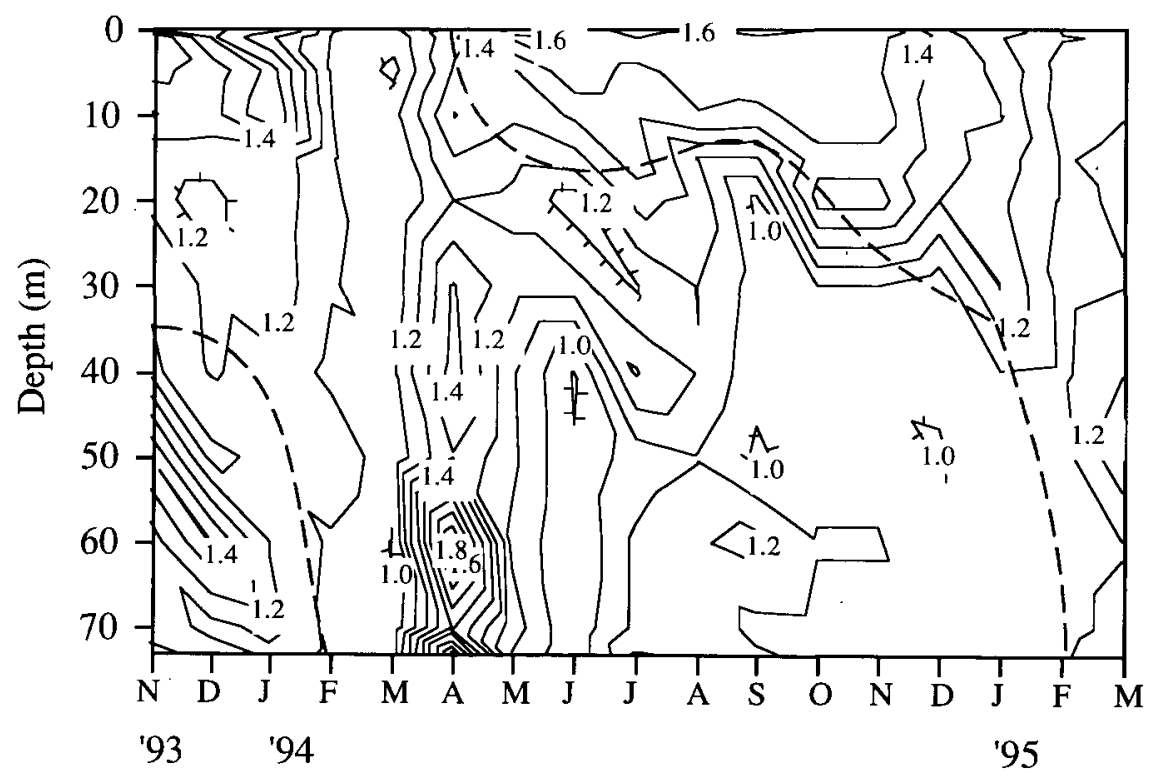

Date (month)

Fig. 2. Serial changes of the vertical distribution of tot-DOC observed at site Ie-1 during the period from November 1993 to March 1995. The DOC concentration is contoured in terms of $\mathrm{mg} \mathrm{Cl}^{-1}$. Regarding the position of the thermocline, the depth is indicated by broken lines. 
Mitamura and SAIJOH (1981) measured DOC at the same site during the period from July 1971 to July 1972. Although relatively higher DOC concentrations were reported due to differences in the measuring method and conditions, almost the same distribution patterns were observed, the average concentration being $1.62 \mathrm{mg} \mathrm{C} \mathrm{l}^{-1}$ with a maximum and minimum of 3.7 and $1.0 \mathrm{mg} \mathrm{C} \mathrm{l}^{-1}$. Based on the observations made by Mitamura and SAIJOH and by the present authors, it can be said that DOC in Lake Biwa seems to have a steady and basic concentration around $1.0 \mathrm{mg} \mathrm{Cl}^{-1}$, to which extra amounts of DOC are occasionally added at the surface and bottom layers. No sign of diffusion of DOC from the bottom sediment was observed. The DOC is clearly supplied by the particulate organic matter suspended in the lake water.

In the subsequent laboratory experiments and discussions, we therefore focused on two types of variations in the DOC concentration, i.e., a slight variation that remained at a basic concentration level, and a larger variation over time in the epilimnion and hypolimnion. To test these variations, we took DOC samples at depths of $5 \mathrm{~m}$ and $60 \mathrm{~m}$ at site Ie-1 and examined their chemical and physicochemical nature by comparing their adsorption behaviors onto HIO and the labilities against permanganate oxidant. For comparison, DOC samples were also taken from the surface at the Akanoi site.

\section{LABORATORY EXPERIMENTS}

\section{Separation of tot-DOC into act- and int-DOC fractions based on their adsorption behaviors to HIO}

According to the procedure shown in the left half of Fig.1, an approximately $80-\mathrm{ml}$ aliquot of each DOC sample was taken in a polycarbonate centrifugation tube and mixed with a 2-ml aliquot of HIO suspension. After the $\mathrm{pH}$ of the samples was adjusted to a desired value by adding negligible volumes of $\mathrm{NaOH}$ or $\mathrm{HCl}$ solution, the samples were shaken for $5 \mathrm{hr}$ by a mechanical shaker working at $100 \mathrm{~Hz}$ under chilled $\left(15^{\circ} \mathrm{C}\right)$ and dark conditions. When adsorption equilibrium was attained, the $\mathrm{pH}$ was measured and the HIO was removed by filtration, followed by the measurement of the DOC in the filtrate. The percent adsorption was calculated from the difference between the DOC concentrations before and after the adsorption.

Figure 3 shows a representative adsorption curve, where the adsorption percent, that is, the portion of adsorbed DOC against the total DOC, is plotted as a function of the $\mathrm{pH}$ at equilibrium. It can be seen from the curve that the adsorption of DOC becomes noticeable below $\mathrm{pH}$ 8.5. As the $\mathrm{pH}$ decreases from 8.5, the adsorption percent increases sharply, reaches a constant around $60 \%$ at $\mathrm{pH} 6$, and then decreases rapidly to zero below $\mathrm{pH}$ 4.0 (where HIO becomes colloidal). According to the flat region of the

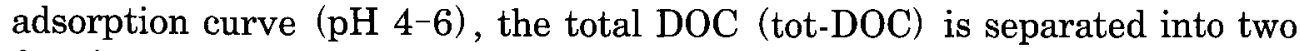
fractions ; one is adsorbed and the other is not. That is,

$$
\text { tot-DOC }=\text { act-DOC }+ \text { int-DOC }
$$

where "act-DOC" is the fraction that is adsorption active in $\mathrm{pH} \mathrm{4-6}$ and 


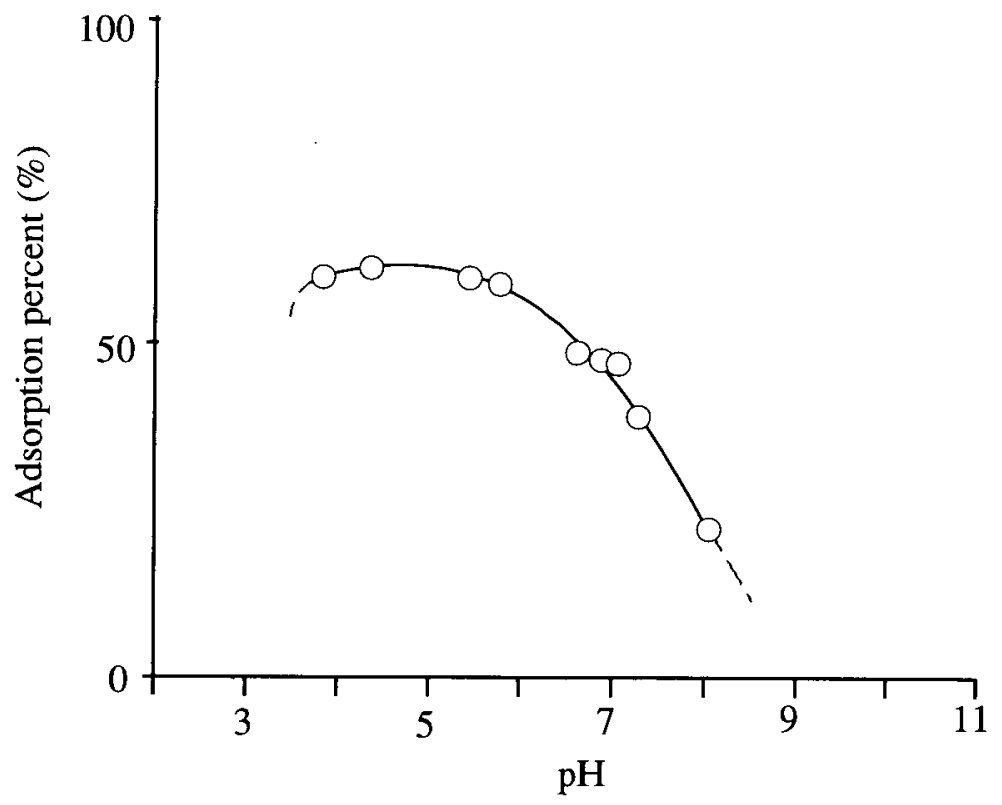

Fig. 3. Adsorption percent of DOC to HIO as a function of $\mathrm{pH}$ (adsorption curve). An $80-\mathrm{ml}$ aliquot of DOC sample was shaken with $2 \mathrm{ml}$ of $\mathrm{HIO}$ suspension with varying $\mathrm{pH}$ values. At equilibrium, the HIO was remove by filtration, and the DOC in the filtrate was measured. The percent of DOC adsorbed by $\mathrm{HIO}$ was calculated and plotted against the $\mathrm{pH}$ at equilibrium.

"int-DOC" is the fraction that is adsorption inactive or inert in the same $\mathrm{pH}$ region. In the case presented in Fig. 3, tot-DOC was divided into $62 \%$ act-DOC and $38 \%$ int-DOC.

Interestingly, irrespective of the changes in sampling sites, depths, and dates, similar shapes of adsorption curves were attained on all samples collected from Lake Biwa. In addition, it was found that the contents of actand int-DOC in a given sample were little changed by increasing the amounts of HIO from 40 to $400 \mathrm{mg}$ as Fe. These findings suggest that the adsorptivity of DOC onto HIO could be one of the practical measures to elucidate the nature of $\mathrm{DOC}$ in natural waters.

It is also noteworthy that act-DOC, once adsorbed on HIO, can be desorbed almost completely from the HIO by increasing the $\mathrm{pH}$ above 9 . In this regard, the adsorption characteristics of act-DOC resemble those of a family of organic molecules with functional groups of - $\mathrm{COOH}$ and -OH (HoRI et al., 1994), and do not resemble those of organic phosphorus compounds (HoRI and SugiYama, 1992), because the adsorption of the latter molecules onto $\mathrm{HIO}$ is not reversible with the change of $\mathrm{pH}$.

\section{Seasonal variation of act-DOC and stability of int-DOC throughout the year}

Act- and int-DOC, which are distinguished according to their adsorptivities onto $\mathrm{HIO}$, are also distinguishable by their variations with time, as 


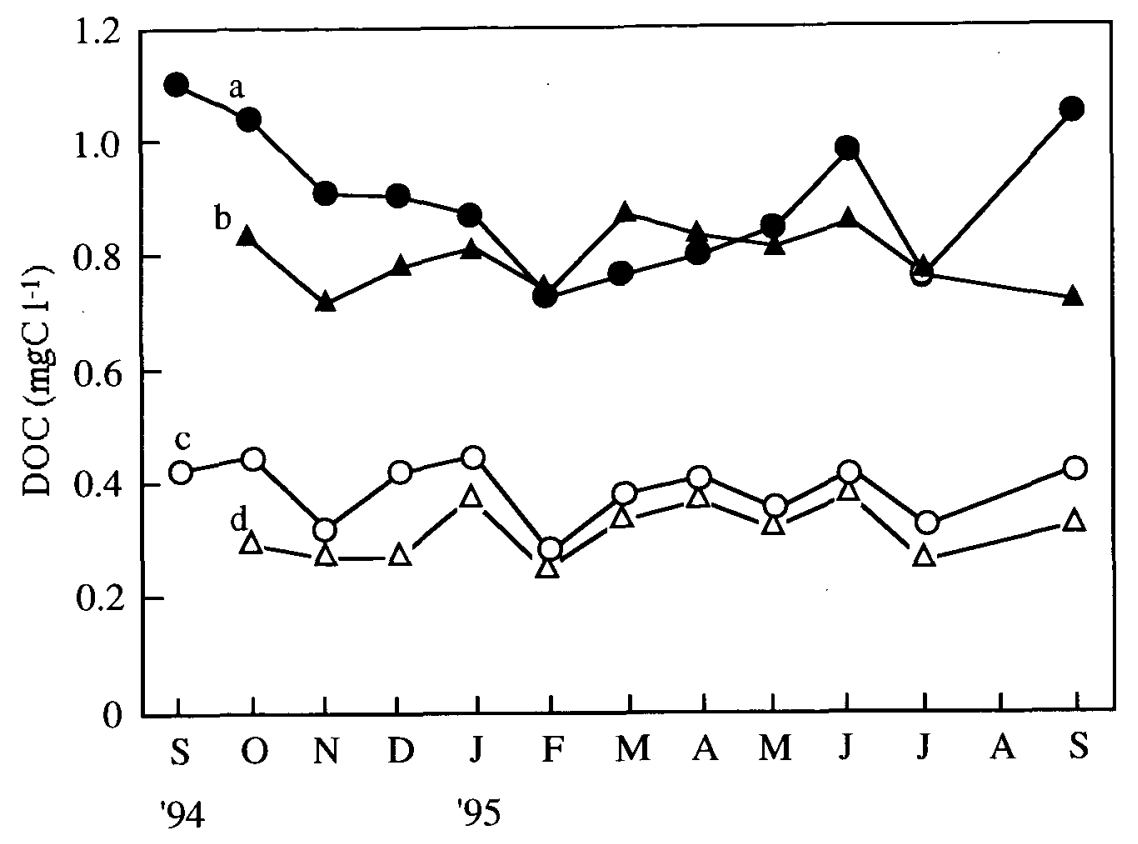

Date (month)

Fig. 4. Monthly variations of act-DOC observed at site Ie-1 at $5 \mathrm{~m}$ (curve a) and 60 $\mathrm{m}$ depths (curve b) and int-DOC at $5 \mathrm{~m}$ (curve c) and $60 \mathrm{~m}$ depths (curve $\mathrm{d}$ ).

depicted in Fig. 4.

Act-DOC at the $5 \mathrm{~m}$ depth of site Ie-1 started to decrease in September and reached the lowest concentration (near $0.8 \mathrm{mg} \mathrm{C}^{-1}$ ) in February (when a thermal convection occurs in the whole lake), then increased gradually toward the highest concentration (around $1.1 \mathrm{mg} \mathrm{C} \mathrm{l}^{-1}$ ) in September. The high concentrations of act-DOC that occurred in spring-summer seemed to depend on the blooming and growth of plankton in the lake. In contrast, the act-DOC in the hypolimnion (at the $60 \mathrm{~m}$ depth of site Ie-1) remained in the relatively narrow concentration range of $0.8 \pm 0.1 \mathrm{mg} \mathrm{C} \mathrm{l}^{-1}$, showing little dependence on the season.

As also shown in Fig. 4, the int-DOC in both the epilimnion and hypolimnion varied little, remaining in the narrow range of $0.35 \pm 0.05$ throughout the year. Moreover, the int-DOC concentrations at site Ie-1 were essentially the same as those observed at the highly eutrophicated site, Akanoi. Thus, int-DOC can be said to be "inert" not only chemically but also biologically and to exist uniformly over the entire lake.

\section{Reactions of act- and int-DOC with permanganate oxidant}

As described in Fig. 1, COD was measured on DOC samples obtained both with and without the HIO adsorption at $\mathrm{pH} 4-6$. The COD value measured with the HIO adsorption was assigned to int-DOC, and the difference in COD 


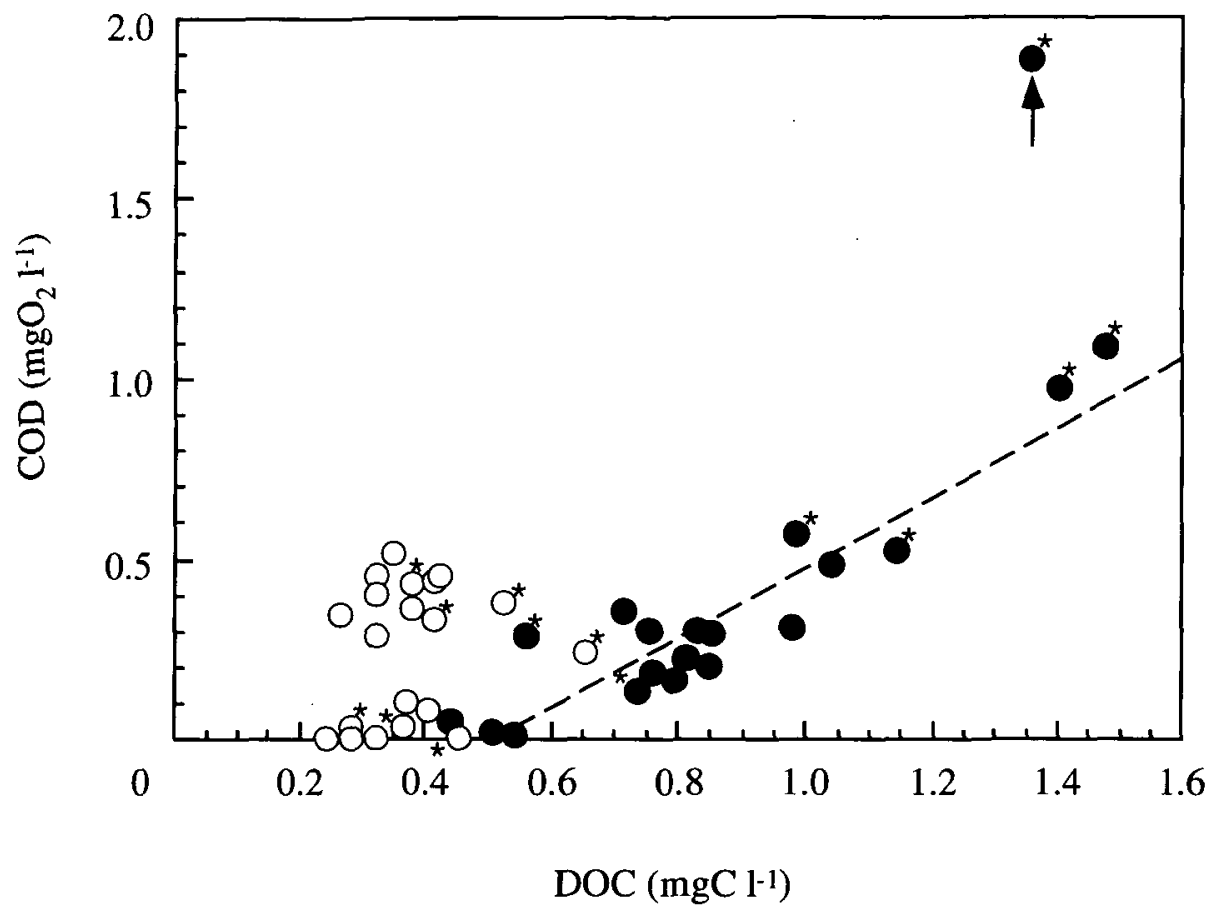

Fig. 5. Plots of act-DOC us. act-COD (closed circles) and of int-DOC vs. int-COD (open circles). On the former plot, a regression analysis was performed and the approximated straight line was superimposed; here, the extraordinarily deviant datum indicated by an arrow was ommitted from the regression analysis. The data indicated by asterisks were obtained with the sample taken at the Akanoi site.

values between the pair of samples with and without the HIO adsorption was assigned to act-DOC. That is, the COD arising from act-DOC, i.e., act-COD, was calculated with known int-COD and tot-COD values in the following equation :

$$
\text { tot-COD }=\text { act-COD }+ \text { int-COD }
$$

In Fig. 5, the relationships between the DOC (act- and / or int-DOC) and the corresponding COD (act- and / or int-COD, respectively) are plotted. A strong correlation was observed between act-DOC and act-COD, even though these samples were collected from the sites in widely different trophic states such as meso- and eutrophic levels. By applying regression analysis, the relation was approximated to a straight line expressed as

$$
\text { act-COD }\left(\mathrm{mg} \mathrm{O}_{2} \mathrm{l}^{-1}\right)=0.97 \times \text { act-DOC }\left(\mathrm{mg} \mathrm{C} \mathrm{l}^{-1}\right)-0.50\left(r^{2}=0.85\right)
$$

The regression line is superimposed in Fig. 5 as a broken line.

The slope of the regression line is an important clue into the nature and origin of act-DOC. For this purpose, analogous regression lines between DOC and COD were measured by employing a selection of reference standard materials such as BSA (as a representative of proteins), soluble starch (a representative of carbohydrates), and fulvic and humic acids which were 


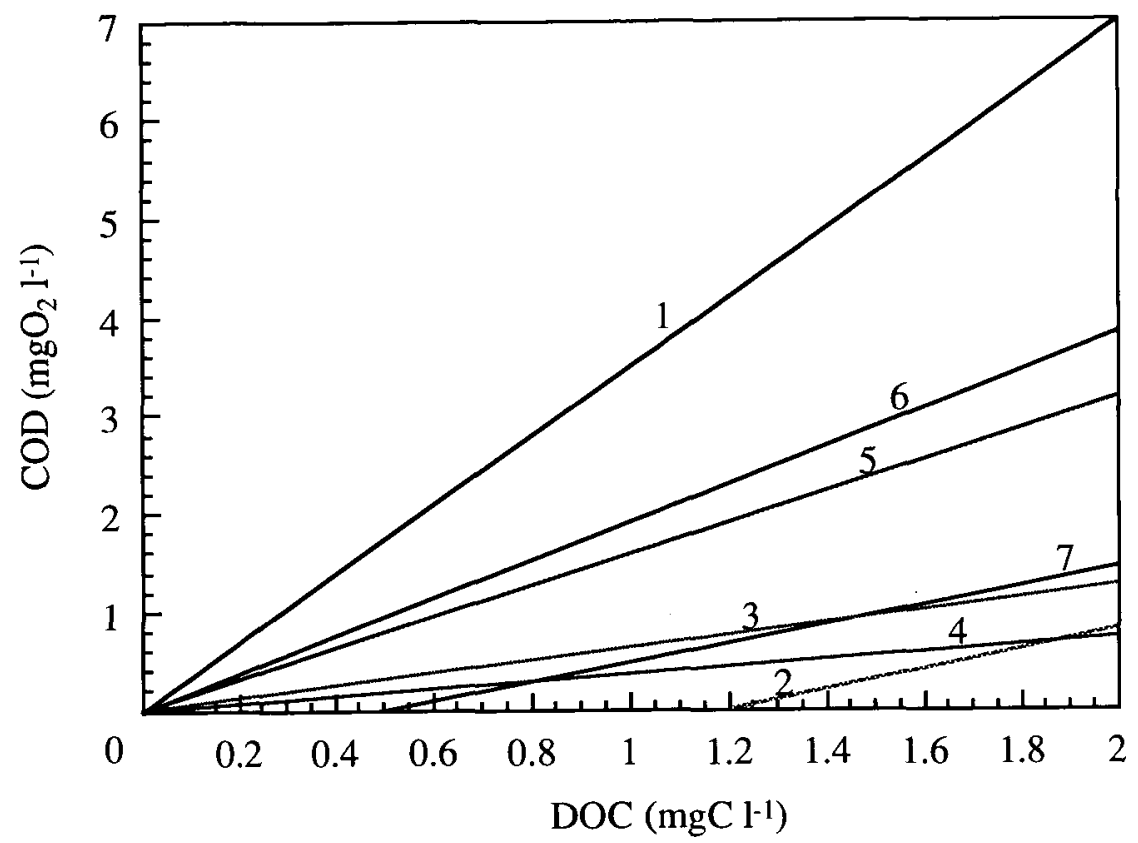

Fig. 6. Comparison of the relationships between COD and DOC : curve (1) : a reference line calculated from the Redfield ratio ; curve (2) : the relation reported by OGURA et al. on seawater samples taken from Tokyo Bay; curves $(3)-(6)$ : relations determined in the present work with BSA, starch, fulvic acid, and humic acid, respectively; curve (7) : relation of act-COD and act-DOC using the plot shown in Fig. 5.

extracted from the sediments of Lake Biwa. The resulting regression lines are illustrated in Fig. 6.

Curve 1 in Fig. 6 is a reference line calculated from the Redfield ratio (REDFIELD, 1963), by assuming that the chemical reaction

$$
\begin{aligned}
\left(\mathrm{CH}_{2} \mathrm{O}\right)_{106}\left(\mathrm{NH}_{3}\right)_{16} \mathrm{H}_{3} \mathrm{PO}_{4}+138 \mathrm{O}_{2} & \\
=106 \mathrm{CO}_{2}+16 \mathrm{HNO}_{3} & +\mathrm{H}_{3} \mathrm{PO}_{4}+122 \mathrm{H}_{2} \mathrm{O}
\end{aligned}
$$

proceeds completely rightward. Since the COD corresponding to $1 \mathrm{mg} \mathrm{C} \mathrm{l}^{-1}$ organic carbon was calculated to be $3.5 \mathrm{mg} \mathrm{O}_{2} \mathrm{l}^{-1}$, the line showed a slope of 3.5. Curve 2 is the plot of COD vs. DOC that was observed by OGURA and TsuBota (1975) with seawater samples taken from Tokyo Bay. The curves $3,4,5$, and 6 are analogous plots performed on the respective materials of BSA, soluble starch, and fulvic and humic acids. Curve 7 is the line for the act-COD vs. act-DOC plot which was transferred from Fig. 5 .

The slope for act-DOC (0.97) is larger compared with those of BSA (0.56) and soluble starch $(0.36)$, that is, the former has a chemical nature to react with permanganate oxidant more easily than the latter two ; in other words, act-DOC contains functional groups or branches that are more easily oxidizable. Inversely, it is smaller compared with those of humic acid (1.9) and fulvic acid (1.6). That is, act-DOC was less reactive with permanganate than the humic and fulvic acids. 
Thus, the essential part of act-DOC seems to have an intermediate nature between the fresh bioproducts (e.g., proteins and starch) and the humus substances (e.g., humic and fulvic acids) with respect to their redox natures, although it is not yet known whether the act-DOC was produced in the lake or carried from the hinterland by riverwaters. We refer to this oxidizable part of act-DOC as act-DOC[ox].

Reverting to Fig. 5 , it can be seen that the regression line for the plot of act-COD vs. act-DOC had an intercept around $0.51 \mathrm{mg} \mathrm{Cl}^{-1}$, indicating that this amount of carbon is not easily oxidized by permanganate. We named this unoxidizable fraction of act-DOC as act-DOC[un].

In contrast, as also shown in Fig. 5, int-DOC has no clear relation to int-COD and remained mostly constant within $0.4 \pm 0.13 \mathrm{mg} \mathrm{C} \mathrm{l}^{-1}$, whereas the corresponding int-COD varied from 0 to $0.55 \mathrm{mg} \mathrm{O} \mathrm{O}_{2} \mathrm{l}^{-1}$. This finding suggested that unknown compounds other than organic carbon may coexist and give additional COD values to int-DOC. Indeed, it has been pointed out in previous studies that the correlation between $\mathrm{COD}$ and biochemical oxygen demand (BOD) in Lake Biwa is rather weak (MATSUI and FUKADA, 1995). The unoxidizable part of int-DOC, i.e., int-DOC[un] can thus be estimated as around $0.4 \mathrm{mg} \mathrm{C}^{-1}$, and the "unoxidizable DOC" in Lake Biwa is around $0.91 \mathrm{mg} \mathrm{C} \mathrm{l}^{-1}$ as the sum of $0.51 \mathrm{mg} \mathrm{Cl}^{-1}$ of act-DOC[un] plus 0 . $4 \mathrm{mg} \mathrm{Cl}^{-1}$ of int-DOC[un]. Incidentally, the concentration of $0.91 \mathrm{mg} \mathrm{C} \mathrm{I}^{-1}$ for the "unoxidizable DOC" is close to the $1.2 \mathrm{mg} \mathrm{C} \mathrm{l}^{-1}$ concentration of "refractory DOC" which was obtained by the following equation derived for seawater samples at Tokyo Bay by OGURA and TsuBota (1975).

$\operatorname{COD}\left(\mathrm{mg} \mathrm{O}_{2} \mathrm{l}^{-1}\right)=1.0 \times \mathrm{DOC}\left(\mathrm{mg} \mathrm{C} \mathrm{l}^{-1}\right)-1.2$

This type of "unoxidizable" or "refractory" DOC seems to be an ordinary fraction of DOC and is anticipated to be present ubiquitously in natural water, reflecting the inherent limnological and geological nature of the water basins.

\section{CONCLUSION}

In a typical harmonic lake, Lake Biwa, the distribution and circulation of DOC were observed. In the lake, DOC showed a basic and steady concentration around $1 \mathrm{mg} \mathrm{C}^{-1}$, to which an additional $0 \sim 0.6 \mathrm{mg} \mathrm{C} \mathrm{l}^{-1}$ of DOC was present in the epilimnion during the warm season and $0 \sim 0.8 \mathrm{mg} \mathrm{C}^{-1}$ of DOC occasionally in the hypolimnion. In parallel with the field observations, laboratory experiments were performed to determine the adsorption of DOC onto HIO and the oxidation with permanganate. The tot-DOC was separated into three fractions ; the first is that adsorbed on HIO and oxidized easily with permanganate (named act-DOC $[\mathrm{ox}]$ ) ; the second is adsorbed on HIO but unoxidizable with permanganate (act-DOC[un]) ; the third is neither adsorbed nor oxidized easily (int-DOC $[\mathrm{un}]$ ). In Lake Biwa, the sum of 0.51

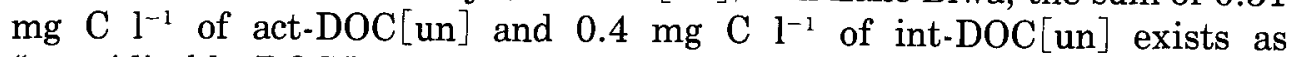
"unoxidizable DOC" and distributes uniformly over the entire lake. The concentration of act-DOC $[\mathrm{ox}]$ varied from 0 to $0.6 \mathrm{mg} \mathrm{C} \mathrm{l}^{-1}$ depending on 
the time in the epilimnion, and varied from 0 to $0.8 \mathrm{mg} \mathrm{C} \mathrm{I}^{-1}$ irregularly in the hypolimnion. A DOC fraction which is not adsorbed on HIO and easily oxidized, i.e., int-DOC $[\mathrm{ox}]$, may not exist at an appreciable concentration.

\section{ACKNOWLEDGEMENTS}

The authors are grateful to the faculty members of the Center for Ecological Research, Kyoto University, for the use of their observation facilities on Lake Biwa. The authors are indebted to Dr. T. TAKAMATSU of the National Institute of Environmental Studies, for his gift of humic and fulvic acids extracted from Lake Biwa sediments. We are also indebted to Emeritus Professor T. FuJINAGA of Kyoto University and Professor N. OGURA of Tokyo University of Agriculture and Technology for their helpful comments and advice on this research.

\section{REFERENCES}

AMON, R. M. W. and R. BENNER (1994) : Rapid cycling of high-molecular-weight dissolved organic matter in the ocean. Nature, 369: 549-551.

Center for Ecological Research, Kyoto Univ. : Unpublished data.

FujINAGa, T. and T. HoRI (1982) : Biwa-ko no kankyo kagaku. [Environmental chemistry of lake Biwa]. The Japan Society for Promotion of Sciences, Tokyo (in Japanese).

HAYES, M. H. B. (1985) : Extraction of humic substances from soil. In Humic substances in soil, sediment, and water. - Geochemistry, isolation, and characterization - G. R. Aiken, D. M. McKnight, R. L. Wershaw, and P. MaCCARTHY (ed.) : 329-362. Wiley-Intersci., New York.

Hori, T. and M. Sugryama (1992) : Use of hydrous iron (III) oxide in a concentration step for the determination of trace amounts of organophosphorus com. pounds in aqueous solutions. Analyst, $117: 893-897$.

Hori, T., Y. SugiYama and M. Sugryama (1994): Systematic comparison of adsorption behaviors of carboxylates and their analogues onto hydrous iron (III) oxide. Bunseki Kagaku, 43 : 965-970 (in Japanese).

Hori, T., Y. Sugiyama, M. Kanao, M. Nagai, N. Taniguchi, M. Sugiyama and T. FUJINAGA (1996) : Distribution of some chemical components in Lake Biwa under usual and unusual wet and drought conditions, 1992-1995. Jpn. J. Limnol., 57 : 183-197.

Hori, T., M. Kanao, M. Nagai, N. Taniguchi, Y. Sugiyama, M. Sugryama and T. TAKAMATSU (1997) : Composition and distribution of major, minor, and trace elements contained in waters and deposits collected along the acid river Sukawa, Japan. Trans. Res. Inst. Oceanochem., 10:38-53 (in Japanese).

JAPAN WaterWORKS AssociaTion (1985) : Standard methods for the examination of service water. : 240-243 (in Japanese).

MATSUI, H. and F. FUKADA (1995) : Regulation concerning establishments discharging small quantities of wastewater in lake Biwa basin. The 6th international conference on the conservation and management of lakes. Proc., Vol.3 : 1325-1328. 
Mitamura, O. and Y. SaIJOH (1981) : Studies on seasonal changes of dissolved organic carbon, nitrogen, phosphorus and urea concentrations in Lake Biwa. Arch. Hydrobiol., 91 : 1-14.

OGURA, N. (1972) : Rate and extent of decomposition of dissolved organic matter in surface seawater. Mar. Biol., 13: 89-93.

OGURA, N.' (1974) : Molecular weight fractionation of dissolved organic matter in coastal seawater. Mar. Biol., 24 : 305-312.

OGURA, N. (1975) : Further studies on decomposition of dissolved organic matter in coastal seawater. Mar. Biol., 31 : 101-111.

Ogura, N. and H. Tsubota (1975) : Kaiyo-osen to shihyo-yoso [Research on the indices for marine pollution]. Reports of research project, grant-in-aid for scientific research : 205-210 (in Japanese).

REDfield, A. C., B. H. Ketchum and F. A. Richards (1963) : The influence of organisms on the composition of sea water. In The Sea, Vol. $2: 26-77$. Interscience, New York.

Shiga Prefecture (1995) : Data compilation of phytoplankton in Lake Biwa 1990-1993. The Shiga Prefectural Institute of Public Health and Environmental Science, Otsu, Japan (in Japanese).

TAKamatsu, T : National Institute of Environmental Studies, Tsukuba, Japan, Private communication.

YoshiokA, R. (1991) : Some problems of water quality in Lake Biwa. Chikyukankyo to oyo-chishitsu : 61-82 (in Japanese).

Toshitaka HorI : Graduate School of Human and Environmental Studies, Kyoto University, Sakyo-ku, Kyoto（堀 智孝：干 606-8501 京都市左京区吉田二 本松町, 京都大学大学院人間・環境学研究科)

Yuko Sugryama : Graduate School of Human and Environmental Studies, Kyoto University, Sakyo-ku, Kyoto（杉山裕子：干 606-8501 京都市左京区吉田二 本松町, 京都大学大学院人間・環境学研究科)

Masahito SugrYama : Faculty of Integrated Human Studies, Kyoto University, Sakyo-ku，Kyoto（杉山雅人：干 606-8501 京都市左京区吉田二本松町，京都 大学総合人間学部)

(Received : 2 July 1997 ; Accepted : 28 November 1997) 


\title{
調和型湖沼琵琶湖に溶存する有機炭素の化学及び 物理化学的特質について
}

\author{
堀 智孝・杉山裕子・杉山雅人
}

\begin{abstract}
摘要
琵琶湖水中の溶存有機炭素 (DOC) の分布には次のような特徴がある。琵琶湖全体にわ たって，また，季節を問わず，約 $1 \mathrm{mg} \mathrm{C} \mathrm{l}^{-1}$ 程度の岀定した DOC 濃度が認められ，この 定常的な DOC 濃度に対して，表層部には暖期（6〜9 月）に0〜0.6 $\mathrm{mg} \mathrm{C}^{-1}$ 程度の DOC が付加され，底層部では時折 0 0.8 $\mathrm{mg} \mathrm{C} \mathrm{l}^{-1}$ の DOC が付加される。以上の観測と並んで, DOC を化学的及び物理化学的手法で分画し，それらの分布と由来を考察した。すなわち， 湖水中のDOCに対して，それが水酸化鉄吸着剤（HIO）に吸着する（act-DOC）か否 (int-DOC) か, 加えて，それが過マンガン酸カリウム酸化剂 $\left(\mathrm{KMnO}_{4}\right)$ で容易に酸化され る（DOC [ox]） か否（DOC [un]）かを調べた。その結果, $\mathrm{HIO}$ に吸着するが $\mathrm{KMnO}_{4}$ で 酸化されにくい分画（act-DOC [un]）は約 $0.51 \mathrm{mg} \mathrm{C} \mathrm{l}^{-1}$, 吸着性も易酸化性も示さない

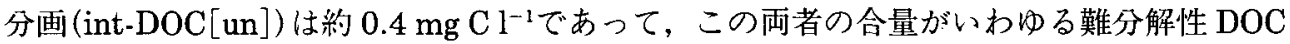
として, 琵琶湖全体に年間を通してほぼ一定した濃度で存在すること, また, 吸着性を示 しかつ易酸化性の分画（act-DOC [ox]）は，表層部で季節に応じて 0 0.6 $\mathrm{mg} \mathrm{C} \mathrm{l}^{-1} て ゙$ 変 動，底層部で不規則に $0 \sim 0.8 \mathrm{mg} \mathrm{C} \mathrm{l}^{-1}$ で変動すること，int-DOC [ $[\mathrm{ox}]$ に相当する分画は 目立って存在しないことが分かった。
\end{abstract}

